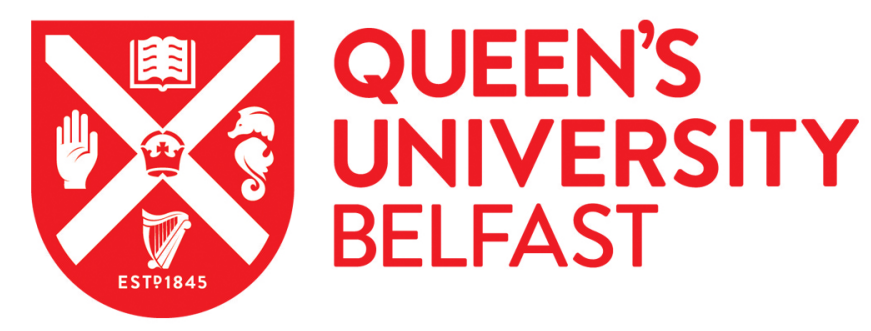

\title{
The production and characterisation of an antibody to detect the coccidiostat toltrazuril and its metabolite ponazuril.
}

Connolly, L., Fodey, T. L., Elliott, C., \& Crooks, S. R. H. (2003). The production and characterisation of an antibody to detect the coccidiostat toltrazuril and its metabolite ponazuril. Analyst, 128(5)(5), 459-461. https://doi.org/10.1039/b301898a

Published in:

Analyst

Queen's University Belfast - Research Portal:

Link to publication record in Queen's University Belfast Research Portal

\section{General rights}

Copyright for the publications made accessible via the Queen's University Belfast Research Portal is retained by the author(s) and / or other copyright owners and it is a condition of accessing these publications that users recognise and abide by the legal requirements associated with these rights.

Take down policy

The Research Portal is Queen's institutional repository that provides access to Queen's research output. Every effort has been made to ensure that content in the Research Portal does not infringe any person's rights, or applicable UK laws. If you discover content in the Research Portal that you believe breaches copyright or violates any law, please contact openaccess@qub.ac.uk. 


\title{
The production and characterisation of an antibody to detect the coccidiostat toltrazuril and its metabolite ponazuril
}

\author{
Lisa Connolly, ${ }^{* a}$ Terence L. Fodey, ${ }^{b}$ Steven R. H. Crooks ${ }^{b}$ and Christopher T. Elliott ${ }^{b}$ \\ a Queens University Belfast, Veterinary Sciences Division, Stoney Road, Belfast, N. Ireland, \\ UK BT4 3SD. E-mail: Lisa_Connolly@yahoo.com \\ ${ }^{b}$ Department of Agriculture and Rural Development for Northern Ireland, Veterinary \\ Sciences Division, Stoney Road, Belfast, N. Ireland, UK BT4 3SD
}

Received 17th February 2003, Accepted 2nd April 2003

First published as an Advance Article on the web 16th April 2003

\begin{abstract}
The production of an antibody to detect toltrazuril or its metabolite ponazuril is complicated due to structural constraints of conjugating these coccidiostats to a carrier protein. Therefore a search was carried out for a compound that shared a common substructure to use as an antigen mimic. The chosen compound, trifluoraminoether, was conjugated to two carrier proteins (HSA and BTG) and used in the immunisation of six rabbits. Two immunogen doses $(1 \mathrm{mg}$ and $0.1 \mathrm{mg}$ ) were also used. All six rabbits produced an immunological response to the hapten regardless of the carrier protein or immunogen dose used. The most sensitive polyclonal antibody produced, designated $\mathrm{R} 609$, was subsequently characterised. This antiserum exhibited an $\mathrm{IC}_{50}$ of $18 \mathrm{ng}$ $\mathrm{ml}^{-1}$ using a competitive ELISA format. Cross reactivity studies show that this serum is specific for toltrazuril and its metabolites (toltrazuril sulfoxide and toltrazuril sulfone) but does not cross-react with other coccidiostats such as halofuginone, nitroimidazoles or nicarbazin. This is the first reported production of an antibody capable of specifically binding toltrazuril and ponazuril.
\end{abstract}

\section{Introduction}

Testing for the presence of veterinary drug residues in foods has become an important issue with regards to food quality and safety. The coccidiostat, toltrazuril, is used to prevent and control the spread of coccidiosis in poultry. It is metabolised to toltrazuril sulfoxide and its associated marker residue, toltrazuril sulfone also known as ponazuril. Toltrazuril is prohibited as a veterinary medical product for egg-producing animals in EU (Council Regulation (EEC) N\|-2377/901). The MRL (maximum residue limit) of the marker residue ponazuril in both chicken and turkey is set at $600 \mu \mathrm{g} \mathrm{kg}^{-1}\left(\mathrm{ng} \mathrm{g}^{-1}\right)$ in liver, $100 \mu \mathrm{g} \mathrm{kg}^{-1}\left(\mathrm{ng} \mathrm{g}^{-1}\right)$ in muscle, $400 \mu \mathrm{g} \mathrm{kg}^{-1}\left(\mathrm{ng} \mathrm{g}^{-1}\right)$ in kidney and $200 \mu \mathrm{g} \mathrm{kg}^{-1}\left(\mathrm{ng} \mathrm{g}^{-1}\right)$ in skin and fat. Detection methods for ponazuril are few. To our knowledge a limited number of papers have been published in which serum was analysed by HPLC. ${ }^{2-4}$ As a result the enforcement of the set MRL is difficult. The development of antibodies and immunochemical methods for the determination of coccidiostats in poultry production, as an alternative to the conventional microbiological or chemical methods, has become more popular in recent years. ${ }^{5,6}$ Immunoassay procedures to detect contaminants in foods and feeds have an advantage over conventional methods in that they are highly specific, simple, rapid, a laborious sample clean-up procedure is not usually required and a high sample throughput is possible. Furthermore, immunoassays do not usually require expensive instrumentation and results are easily interpretable by individuals with limited training.

In order to screen large numbers of samples for toltrazuril residues by immunological methods such as ELISA, a specific antibody to the metabolite ponazuril is required. To elicit an immune response in the host animal a small compound such as ponazuril must be conjugated to a large (immunogenic) carrier protein. The structures of toltrazuril (Fig. 1), ponazuril (Fig. 2) and toltrazuril sulfoxide (Fig. 3) lack a functional group that would facilitate conjugation to a protein. It was considered that compounds which share a portion of the ponazuril structure (antigen mimics) could be used to raise antibodies that may cross-react with ponazuril. The present workers have previously developed antibodies to the coccidiostat nicarbazin using antigen mimics. ${ }^{7}$ Therefore using the Cs ChemOffice ${ }^{\mathrm{TM}}$ software package (Cambridgesoft Corporation, Cambridge, MA, USA) it was possible to search the database for drugs that contain a similar sub-structure to ponazuril. Trifluoraminoether was identified as one such compound that contains an identical part of both the toltrazuril and ponazuril structures (Fig. 4). This compound also contains an amine group that allows conjugation to a protein carrier.

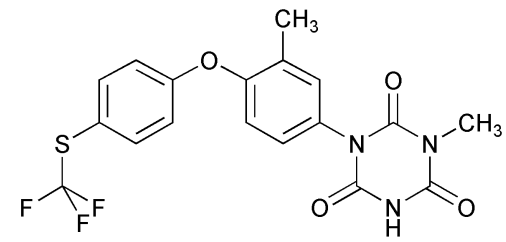

Fig. 1 Chemical structure of toltrazuril.<smiles>Cc1cc(-n2c(=O)[nH]c(=O)n(C)c2=O)ccc1Oc1ccc(S(=O)(=O)C(F)(F)F)cc1</smiles>

Fig. 2 Chemical structure of ponazuril (toltrazuril sulfone).<smiles>Cc1cc(-n2c(=O)[nH]c(=O)n(C)c2=O)ccc1Oc1ccc(S(=O)(=O)C(F)(F)F)cc1</smiles>

Fig. 3 Chemical structure of toltrazuril sulfoxide. 
The present communication outlines the production and characterisation of the first reported toltrazuril/ponazuril specific antibody.

\section{Materials and methods}

\section{Reagents and chemicals}

Toltrazuril, toltrazuril sulfoxide, toltrazuril sulfone (ponazuril) and 4-amino-2-methyl-4-trifluoromethylathiodiphenyl oxide (trifluoraminoether) were all obtained from Bayer Ag (Leverkusen, Germany). Human serum albumin (HSA) (A1887), bovine thyroglobulin (BTG) (T1001), Freunds complete adjuvant (F5881) and Freunds incomplete adjuvant (F5506) were obtained from Sigma (Poole, Dorset, UK). Horseradish peroxidase (HRP) (814407) was purchased from Roche Diagnostics (Lewes, East Sussex, UK) and PD-10 gel filtration columns (17-0851-01) were obtained from Pharmacia (Uppsala, Sweden).

\section{Preparation of immunogens}

Trifluoraminoether was conjugated to HSA and BTG via the diazo reaction of Fleeker and Lovett. ${ }^{8}$ Briefly trifluoraminoether $(10 \mathrm{mg})$ was dissolved in $500 \mu \mathrm{l}$ of dimethylsulfoxide and $1 \mathrm{ml}$ of $0.1 \mathrm{M}$ hydrochloric acid. Sodium nitrite $(250 \mu \mathrm{l}$ of $0.58 \mathrm{M}$ ) was added in $50 \mu \mathrm{l}$ amounts over a period of $5 \mathrm{~min}$. The activated drug was then added in $100 \mu \mathrm{l}$ amounts to the carrier proteins $(50 \mathrm{mg}$ of $\mathrm{HSA}$ or BTG in $1 \mathrm{ml}$ of carbonatebicarbonate buffer, $\mathrm{pH}$ 10). The reaction was allowed to proceed for $4 \mathrm{~h}$ at room temperature before purification by dialysis. The immunogens were split into $1 \mathrm{mg}$ aliquots and stored at $-20{ }^{\circ} \mathrm{C}$.

\section{Preparation of enzyme label}

A horseradish peroxidase conjugate of trifluoraminoether was prepared using the same method as above. On this occasion 20 $\mathrm{mg}$ of peroxidase was used with $5 \mathrm{mg}$ of trifluoraminoether and $100 \mu \mathrm{l}$ of sodium nitrite. The conjugate was purified by gel filtration on a PD-10 sephadex G-25 column and stored at -20 ${ }^{\circ} \mathrm{C}$.

\section{Immunisation of rabbits}

Four New Zealand White rabbits received $0.1 \mathrm{mg}$ immunogen emulsified in Freunds complete adjuvant (divided equally between four injection sites (front and hindquarters)) followed at two weekly intervals with similar booster injections prepared using Freunds incomplete adjuvant. A blood sample was collected for testing two weeks after each immunisation. A further two rabbits were immunised using the same protocol but with $1 \mathrm{mg}$ of immunogen.

\section{Determination of antibody titre}

Blood samples taken from the immunised rabbits were assessed for their antibody content by performing an ELISA chequer-

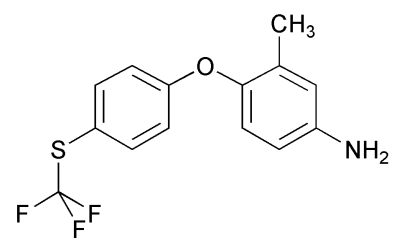

Fig. 4 Chemical structure of trifluoraminoether. board titration using a competitive assay format and peroxidaseconjugate as described below:

Microtitre plates (Falcon 353070) were coated (100 $\mu \mathrm{l}$ well ${ }^{-1}$ ) with serial dilutions of rabbit serum diluted in assay buffer ( $1 \mathrm{mM}$ sodium acetate solution, $\mathrm{pH}$ 7.2) and incubated overnight at room temperature. Ponazuril standard $(50 \mu \mathrm{l})$ diluted to $1 \mathrm{ng} \mu \mathrm{l}^{-1}$ in assay buffer and $50 \mu \mathrm{l}$ of peroxidase conjugate serially diluted in blocking buffer $\left(2 \mathrm{mg} \mathrm{ml}^{-1} \mathrm{w} / \mathrm{v}\right.$ BSA in assay buffer) were added to competitive wells. Control wells containing all components except the competitor were also included. The assay was then incubated at $37{ }^{\circ} \mathrm{C}$ for $2 \mathrm{~h}$. After 12 washes with wash buffer $(0.9 \%$ sodium chloride, $0.1 \%$ Tween 20) bound antibody peroxidase-conjugate was measured using TMB/E (Chemicon International ES001), a colorimetric substrate. Absorbance was read at $450 \mathrm{~nm}$ after $12 \mathrm{~min}$ on a BioTek ELISA plate reader. The activity (colour development) in control wells was taken to represent $100 \%$.

\section{Assessment of antibody sensitivity}

The competitive ELISA format (described above) was used to determine the sensitivity of the polyclonal antibodies. The optimum serum and peroxidase-conjugate dilutions were predetermined by the chequerboard titration results.

A set of ponazuril standards (in the range of 0 to $1000 \mathrm{ng}$ $\left.\mathrm{ml}^{-1}\right)$ was prepared in assay buffer and added $(50 \mu \mathrm{l}$ well-1). The optimum dilution of peroxidase-conjugate was also added $\left(50 \mu \mathrm{l} \mathrm{well}{ }^{-1}\right)$. The average optical density of zero standard wells, containing all components except the competitor, were taken to represent $100 \%$ activity of the peroxidase conjugate and the remaining standards were normalised relative to the optical density of the zero standard. The midpoint of the curve was calculated in order to determine the $\mathrm{IC}_{50}$.

\section{Assessment of antibody specificity}

Determination of cross reactivities to a range of other coccidiostats (halofuginone, nicarbazin and nitroimidazoles) was tested by determining their $\mathrm{IC}_{50}$ values in the competitive ELISA described above. The cross reactivity values were calculated as:

Cross reactivity $=\mathrm{IC}_{50}$ of Ponazuril//C $\mathrm{IC}_{50}$ of competitor $\times 100$

\section{Results}

\section{Antibody titre}

Sera from all six rabbits displayed antibody titres to ponazuril. Details of the immunised rabbits are displayed in Table 1. An immune response was elicited in all six rabbits immunised, regardless of protein carrier or dose used. However, rabbit R609

Table 1 Details of immunisation regime for each of the six rabbits and their relative response

\begin{tabular}{lllll}
\hline & & & & $\begin{array}{l}\text { Amount/ } \\
\text { fisplacement } \\
\text { from 50 ng }\end{array}$ \\
Animal no. & $\begin{array}{l}\text { Carrier } \\
\text { protein } \\
\text { immunisation }\end{array}$ & $\begin{array}{l}\text { No. of } \\
\text { immunisations }\end{array}$ & $\begin{array}{l}\text { ponazuril } \\
\text { standard }\end{array}$ \\
\hline R592 & HSA & $1 \mathrm{mg} / 2$ weeks & 10 & 45 \\
R597 & BTG & $1 \mathrm{mg} / 2$ weeks & 11 & 35 \\
R608 & BTG & $0.1 \mathrm{mg} / 2$ weeks & 5 & 23 \\
R609 & HSA & $0.1 \mathrm{mg} / 2$ weeks & 13 & 86 \\
R631 & HSA & $0.1 \mathrm{mg} / 2$ weeks & 11 & 48 \\
R632 & BTG & $0.1 \mathrm{mg} / 2$ weeks & 11 & 53 \\
\hline
\end{tabular}


was deemed to have given the best response with regards sensitivity and was further characterised.

\section{Antibody sensitivity}

The standard curve obtained for ponazuril using polyclonal antibody R609 is shown in Fig. 5. R609 exhibited a relative affinity for ponazuril with an $\mathrm{IC}_{50}$ of $18.0 \mathrm{ng} \mathrm{ml}^{-1}$.

\section{Antibody specificity}

R609 was further characterised with regards selectivity. The cross-reactivity of the R609 antibody with ponazuril and other coccidiostat compounds was determined by competitive ELISA as described earlier. Table 2 presents the results as percentage cross-reactivity. The data shows that R609 is specific for ponazuril and did not show significant cross reactivity with halofuginone, nicarbazin or nitroimidazoles. Higher cross reactivity with toltrazuril was predicted, as the selected mimic had greatest structural similarities to it, compared with ponazuril (i.e. sulfur not oxidised).

\section{Discussion}

The need for rapid assays capable of detecting coccidiostat residues in poultry produce is of the utmost importance as the

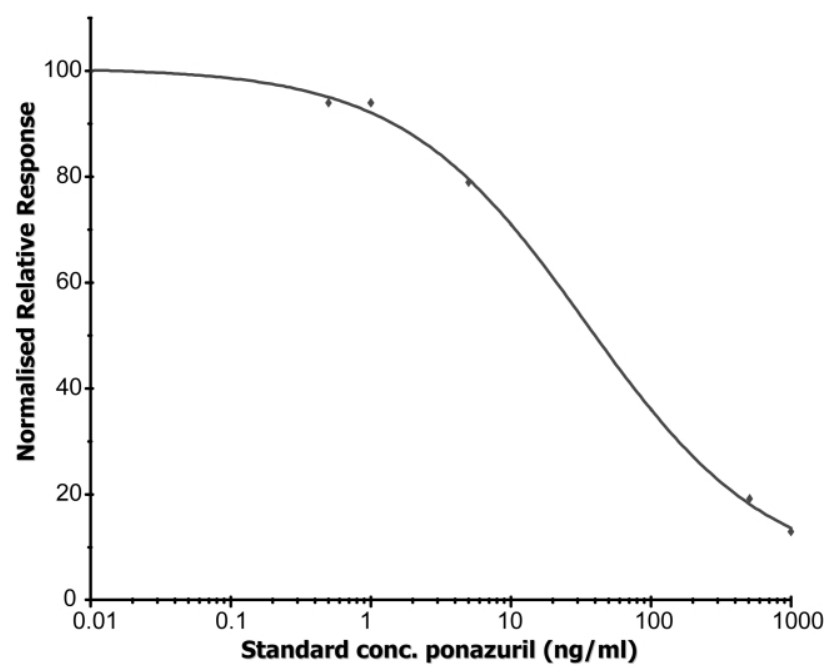

Fig. 5 Standard curve produced using the R609 polyclonal antibody and diazotrifluoraminoether-HRP conjugate. The curve gives an $\mathrm{IC}_{50}$ of $18 \mathrm{ng}$ $\mathrm{ml}^{-1}$.

Table 2 Cross reactivity data for R609

\begin{tabular}{lc}
\hline Coccidiostat & $\%$ Cross reactivity \\
\hline Ponazuril (Totrazuril sulfone) & 100 \\
Toltrazuril & 118 \\
Toltrazuril sulfoxide & 61 \\
Clazuril & $<0.01$ \\
Diclazuril & $<0.01$ \\
Halofuginone & $<0.01$ \\
Ronidazole & $<0.01$ \\
Metronidazole & $<0.01$ \\
\hline
\end{tabular}

relationship between residue content and meat quality is becoming a significant issue. Detection methods based on immunoassays can greatly increase sample throughput, and allow the screening of increased numbers of samples without increasing the cost of analysis. This publication has outlined the development and characterisation of the first reported polyclonal antibody to ponazuril, as well as the development of a competitive indirect enzyme linked immunosorbent assay.

The production of an antibody to detect toltrazuril residues was complicated by the fact that conjugation of the marker residue, ponazuril, to a carrier protein was not straightforward due to the lack of reactive groups on this compound. To overcome this problem an antigen mimic was used (compound with a similar structure to free ponazuril) to produce a polyclonal antibody which can detect free ponazuril. In the present study selection of a mimic was performed by searching a database for a compound that shared a portion of the structure of ponazuril. Trifluoraminoether was identified and sourced from the company of manufacture, thus eliminating the need for complex antigen synthesis. The antigen mimic was also used to produce an enzyme labeled conjugate.

The choice of carrier protein (HSA or BTG) and immunogen dose $(1 \mathrm{mg}$ or $0.1 \mathrm{mg})$ did not influence immune response. An immune response was elicited in all six rabbits immunised, regardless of protein carrier or dose used. However, rabbit R609 gave the best response with regards sensitivity and specificity.

The sensitivity of the resulting R609 antibody was determined using a competitive ELISA assay and expressed in terms of $\mathrm{IC}_{50}$ values. This antibody is capable of detecting ponazuril at $18.0 \mathrm{ng} \mathrm{ml}^{-1}$. Cross-reactivity data involving other coccidiostats (halofuginone, nicarbazin and nitroimidazoles) were also obtained and demonstrates that the R609 polyclonal recognises toltrazuril and its metabolites specifically. The sensitivity and specificity of the R609 antibody described in this paper would appear to be adequate to allow detection of toltrazuril residues well below the established MRL in liver. Therefore, it may be used to establish an immunoassay for liver samples.

\section{Acknowledgements}

This research and development was undertaken as part of The Poultry-check project (QLK1-CT-1999-00313); carried out with support from The European Union in the framework of the programme "Quality of Life and Management of Living Resources".

\section{References}

1 Council regulation 2377/90, Official Journal of European Communities, 1990, No. L224/1.

2 M. Furr and T. Kennedy, Vet. Therapeutics, 2001, 2, 231-237.

3 E. Benoit, T. Buronfosse and P. Delatour, Chirality, 1994, 6((5)), 372-377.

4 S. Kritzner, H. Sager, J. Blum, R. Krebber, G. Greif and B. Gottstein, Ann. Clin. Microbiol. Antimicrobials, 2002, 1, 4.

5 U. Samarajeewa, C. I. Wei, T. S. Huang and M. R. Marshall, Crit. Rev. Food Sci. Nutr., 1991, 29, 403-434.

6 L. H. Stanker, M. H. Elissalde, L. D. Rowe, R. C. Beier and M. I. A. EL-Aziz Nasr, Food Agric. Immunol., 1994, 6, 45-54.

7 L. Connolly, T. L. Fodey, S. R. H. Crooks, P. H. Delahaut and C. T. Elliott, J. Immunol. Methods, 2002, 264, 45-51.

8 J. R. Fleeker and L. J. Lovett, J. AOAC Int., 1985, 88, 172-174. 